\title{
Internalization of a Bacillus anthracis Protective Antigen-c-Myc Fusion Protein Mediated by Cell Surface Anti-c-Myc Antibodies
}

\author{
Mini Varughese, Angela Chi, Avelino V. Teixeira, \\ Peter J. Nicholls, Jerry M. Keith, and Stephen H. Leppla \\ Oral Infection and Immunity Branch, National Institute of Dental \\ Research, NIH, Bethesda, Maryland, U.S.A. \\ Communicated by I. Pasten. Accepted December 15, 1997.
}

\begin{abstract}
Background: Anthrax toxin, secreted by Bacillus anthracis, consists of protective antigen (PA) and either lethal factor (LF) or edema factor (EF). PA, the receptor-binding component of the toxin, translocates LF or EF into the cytosol, where the latter proteins exert their toxic effects. We hypothesized that anthrax toxin fusion proteins could be used to kill virus-infected cells and tumor cells, if PA could be redirected to unique receptors found only on these cells.
\end{abstract}

Materials And Methods: To test this hypothesis in a model system, amino acids 410-419 of the human p62 ${ }^{\mathrm{c}-m y c}$ epitope were fused to the C-terminus of PA to redirect PA to the c-Myc-specific hybridoma cell line $9 \mathrm{E} 10$.

Results: The PA-c-Myc fusion protein killed both mouse macrophages and 9E10 hybridoma cells when adminis- tered with LF or an LF fusion protein (FP59), respectively. Similar results were obtained with PA, which suggests that PA-c-Myc used the endogenous PA receptor to enter the cells. By blocking the endogenous PA receptors on 9E10 cells with the competitive inhibitor PA SNKE $\Delta \mathrm{FF}$, the PA-c-Myc was directed to an alternate receptor, i.e., the anti-c-Myc antibodies presented on the cell surface. The c-Myc IgG were proven to act as receptors because the addition of a synthetic peptide containing the c-Myc epitope along with PA SNKE $\Delta$ FF further reduced the toxicity of PA-c-Myc + FP59.

Conclusion: This study shows that PA can be redirected to alternate receptors by adding novel epitopes to the C-terminus of PA, enabling the creation of cell-directed toxins for therapeutic purposes.

\section{Introduction}

Anthrax toxin is a three-part toxin secreted by Bacillus anthracis consisting of protective antigen

Angela Chi's present address is Harvard School of Dental Medicine, 188 Longwood Avenue, Boston, MA 02115.

Avelino V. Texeira's present address is Division of Nephrology, Mount Sinai School of Medicine, One Gustave L. Levy Place, Box 1243, New York, NY 10029-6574.

Peter J. Nicholls' present address is Department of Biosciences, University of Kent at Canterbury, Canterbury, Kent CT2 7NJ, United Kingdom.

Address correspondence and reprint requests to: Dr. Stephen H. Leppla, Oral Infection and Immunity Branch, National Institute of Dental Research, Bldg. 30, Room 316, 30 Convent Drive MSC 4350, Bethesda, MD 20892-4350, U.S.A. Phone: 301-594-2865; Fax: 301-402-0396; E-mail: leppla@nih.gov
(PA), lethal factor (LF), and edema factor (EF) (1). PA, the receptor-binding component of anthrax toxin, binds an unidentified receptor and then is cleaved by a cell-surface, furin-like protease (2). The cleaved PA binds LF or EF, undergoes receptor-mediated endocytosis $(3,4)$, and forms a pore-like heptameric structure $(5,6)$. The PA pore transfers LF and EF into the cytosol, where they induce cytotoxic events $(6,7)$. When administered to rats intravenously, lethal toxin (the combination of PA and LF) causes pulmonary edema and death in as little as $38 \mathrm{~min}(8,9)$. In cell culture, mouse macrophages lyse completely in 90 min after addition of lethal toxin $(3,10)$. The ability of lethal toxin to rapidly lyse 
cultured cells provides a reliable assay for PA activity.

Several lines of evidence suggest that the C-terminus of PA is the receptor-binding domain. First, the removal of 3, 5, or 7 residues from the carboxyl terminus of PA decreases the toxicity of the PA progressively, creating a final 20 -fold decrease in toxicity (11). These truncated proteins exhibit decreased affinity for the receptor in competition assays, indicating that the receptor-binding domain resides in the C-terminus of PA. Second, two monoclonal antibodies against PA, 14B7 and 3B6, fail to interact with a truncated PA ( 155 amino acids deleted from the C-terminus), but bind to full-length PA (735 amino acids) and inhibit binding of PA to its receptor (12). Third, comparison of the amino acid sequence of PA with that of other binary toxins, such as iota- $b$ toxin from Clostridium perfringens (13), shows high similarity between the toxins, except in the C-terminal domain (14). This suggests that the $\mathrm{C}$-terminal domain confers receptor specificity to $\mathrm{PA}$.

If PA can be redirected to an alternate receptor, anthrax toxin could be used in vivo to kill tumor cells. Before creating a nonreceptor-binding mutant of PA, a model system was tested to determine if intact PA could be directed to and use an alternate receptor. To test this idea, the C-terminus of PA (because the carboxyl end of PA possesses the receptor-binding domain) was fused to the human p62 ${ }^{\mathrm{c}-m y c}$ (15) epitope (amino acids 410-419 (16)) so as to target the antic-Myc hybridoma cell line 9E10 (17). The myc family of proto-oncogenes express DNA binding proteins that affect cell proliferation, apoptosis, and cell-cycle progression (for reviews see refs. $18-20$ ). The c-Myc peptide for our fusion experiment was selected because it contains a wellcharacterized antigenic epitope of c-Myc that is recognized by the anti-c-Myc $9 \mathrm{E} 10$ antibody secreted by the 9E10 hybridoma cell line $(16,17)$. Hybridoma cells both secrete antibody and present antibody on their cell surface. The presented antibody acts as a receptor for its antigen (for reviews on Ig receptors see refs. 21-23). The antibodies to c-Myc presented on the surface of the 9E 10 hybridoma cell may also be capable of acting as receptors for PA-c-Myc and internalizing the protein by receptor-mediated endocytosis. This study shows that through the addition of a cell-specific epitope to the C-terminus of PA, PA can be targeted to alternate receptors and thereby to specific cell lines.

\section{Materials and Methods}

Reagents and Supplies

Enzymes for DNA manipulation and modification were purchased from New England Biolabs, Inc. (Beverly, MA), Boehringer Mannheim (Indianapolis, IN), and Amersham Life Sciences (Arlington Heights, IL). Chemicals for protein work were purchased from Sigma (St. Louis, MO). Tissue culture products were obtained from Biofluids (Rockville, MD) or Life Technologies (Grand Island, NY) and the bacterial culture media from Difco Laboratories (Detroit, MI).

\section{Plasmid Construction}

Using the previously described plasmid, pYS5 (24), the human $p 62^{c-m y c}$ (15) epitope corresponding to amino acid residues 410-419 (EQKLISEEDL) (16) was attached to the 3 '-end of pag, the gene for PA (25). The pYS5 plasmid, encoding pag is an Escherichia coli-Bacillus shuttle vector. A primer spanning the unique PstI site at nucleotide 966 of the mature pag sequence and a 98 nt mutagenic primer overlapping the C-terminal BamHI site of pag were used for polymerase chain reaction (PCR) amplification of pYS5. The mutagenic 3' Bam HI primer encoded the $3^{\prime}$-end of pag (nt 2185 to 2205), a 6-amino acid (GGSGGS) linker, the 10-amino acid c-Myc epitope, two stop codons, the BamHI site, and a short extension of DNA, in this order. After digestion with PstI and BamHI the PCR product from the amplification was ligated into the PstI and BamHI digested pYS5 plasmid and transformed into the $E$. coli dcm dam strain, GM2163. After plasmids had been sequenced to verify the presence of the c-Myc sequence at the 3 '-end of pag, the unmethylated GM2163 DNA was transformed into the Bacillus anthracis strain, UM23C1-1 (26).

\section{Expression and Purification of Protein}

To purify the secreted PA-c-Myc from the medium of transformed $B$. anthracis cultures, the $B$. anthracis was grown in modified FA medium (24) in the presence of kanamycin $(5 \mu \mathrm{g} / \mathrm{ml})$ for 14 $\mathrm{hr}$, at 200 revolutions $/ \mathrm{min}$ and $37^{\circ} \mathrm{C}$. The modified FA media contained a reduced quantity of yeast extract ( $5 \mathrm{~g}$ of yeast extract/liter) as compared with the unmodified FA medium. The PA was precipitated from the filtered culture supernatant by the addition of ammonium sulfate (61\% saturation). The precipitate was concentrated by centrifugation at $4,000 \times g$ for $30 \mathrm{~min}$. 
The precipitated protein was redissolved in $1 \mathrm{mM}$ EDTA, $10 \mathrm{mM}$ Tris, $0.2 \mathrm{M} \mathrm{NaCl}$, pH 8.0, centrifuged at $5000 \times g$ for $5 \mathrm{~min}$, and the supernatant from the centrifugation fractionated by Sephadex G-75 (Pharmacia Biotech, Piscataway, NJ). The fusion protein fractions from the Sephadex column were pooled and separated on a $1-\mathrm{ml}$ MonoQ column (Pharmacia Biotech) using a 50to 200-mM NaCl gradient in $10 \mathrm{mM}$ CHES (2[N-cyclohexylamino]ethane-sulfonic acid), $0.06 \%$ (v/v) ethanolamine, $\mathrm{pH} 9.1$ (2). The pooled MonoQ fractions were dialyzed against $10 \mathrm{mM}$ HEPES, $0.1 \mathrm{M} \mathrm{NaCl}, \mathrm{pH} 8.0$, concentrated with a Centricon 50 (Amicon, Beverly, MA), and analyzed by native $8-25 \%$ Phast gel electrophoresis (Pharmacia Biotech).

\section{Cell Culture}

RAW264.7 cells (mouse macrophages) were cultured in Dulbecco's modified Eagle's medium (DMEM) with 4,500 mg/l D-glucose, $10 \%(\mathrm{v} / \mathrm{v})$ fetal bovine serum (FBS), $50 \mu \mathrm{g} / \mathrm{ml}$ gentamicin, $10 \mathrm{mM}$ HEPES, and $2 \mathrm{mM}$ glutamine. The 9E10.2 hybridoma cells, ATCC 1729-CRL (17), and the SP2/0 Ag 14 myeloma cells, ATCC 1581CRL (27), were maintained in DMEM with 4,500 $\mathrm{mg} / \mathrm{l} \mathrm{D}$-glucose, $10 \%$ (v/v) FetalClone I (HyClone Laboratories, Inc. Logan, UT), $50 \mu \mathrm{g} / \mathrm{ml}$ gentamicin, $10 \mathrm{mM}$ HEPES, $2 \mathrm{mM}$ glutamine, 1:100 dilution of GMS-G (Insulin-TransferrinSelenium supplement) (Life Technologies), 150 $\mu \mathrm{g} / \mathrm{mL}$ oxaloacetate, and $10 \mu \mathrm{g} / \mathrm{ml}$ bovine insulin (Life Technologies).

\section{Antibody Isolation}

The monoclonal antibody from cell culture medium of 9E10.2 hybridoma cells was isolated using the MabTrapG Protein G kit from Pharmacia. Purified antibody was concentrated in a Centricon 50 (Amicon) and dialyzed against $10 \mathrm{mM}$ HEPES, $0.1 \mathrm{M} \mathrm{NaCl}$ pH 8.0. Antibody concentration was determined by spectrophotometry at $280 \mathrm{~nm}$.

\section{ELISA}

For the ELISA, purified PA, PA-c-Myc, or c-Myc peptide (residues 408-439, Calbiochem) was diluted to $10 \mu \mathrm{g} / \mathrm{ml}$ in $10 \mathrm{mM}$ phosphate buffer, pH 9.2, and $75 \mu \mathrm{L}$ of protein or peptide applied per well of a 96-well Immulon II microtiter plate (Dynex Technologies, Chantilly, VA). After washing the microtiter plate with phosphate buffer plus $0.1 \%(\mathrm{w} / \mathrm{v})$ gelatin, $50 \mu$ l of $1: 100$ diluted monoclonal PA antibody 3B6 (12) or monoclonal c-Myc antibody $9 \mathrm{E} 10$ was added to the top set of wells and the antibody was serially diluted 1:3 down the column of wells. The wells were washed and secondary antibody, horseradish peroxidase (HRP)-conjugated goat antimouse IgG (Cappel, Organon Teknika Corporation, Durham, NC), was then added to the samples. The HRP-bound antibody was visualized with $1 \mathrm{mg} / \mathrm{ml}$ of ABTS (2,2' -azinobis[3-ethylbenzthiazoline-sulfonic acid]) in $0.1 \mathrm{M}$ citrate buffer, $\mathrm{pH} 5.0$, and $0.01 \%(\mathrm{w} / \mathrm{v}) \mathrm{H}_{2} \mathrm{O}_{2}$. The absorption at $405 \mathrm{~nm}$ was read using a $\mathrm{UV}_{\max } \mathrm{Ki}$ netic Microplate Reader (Molecular Devices, Menlo Park, CA).

\section{Immunoassays}

To quantitate the relative amounts of mouse IgG presented on the surface of the cells, the 9E10 and the parent SP2/0 cell lines were labeled with anti-mouse IgG and the IgG bound to the cells quantitated by spectrophotometry or analyzed by a fluorescent activated cell sorter (FACS). The cells were washed twice in Hanks buffered saline solution (HBSS), resuspended in phosphatebuffered saline (PBS) plus $0.05 \%(\mathrm{w} / \mathrm{v})$ gelatin, counted in a hemacytometer (Fisher Scientific, Pittsburgh, PA), and then $1 \mathrm{ml}$ of $1.2 \times 10^{5}$ cells/ml used for the spectrophotometric immunoassay. The $1 \mathrm{ml}$ of cells was incubated with 5 $\mu l$ of HRP-conjugated goat anti-mouse IgG (Cappel), washed three times, and resuspended in ABTS and citrate buffer or the resuspended sample diluted 1:10 into ABTS and citrate buffer as per the ELISA protocol above. The amount of cell-bound HRP-conjugated antibody was determined at $405 \mathrm{~nm}$ in the Molecular Devices $\mathrm{UV}_{\text {max }}$ Kinetic Microplate Reader. To prepare cells for the FACS, the cells were pelleted, washed two times in PBS, and counted in a hemacytometer. One milliliter of $1 \times 10^{5}$ cells $/ \mathrm{ml}$ was then placed into $5 \mathrm{ml}$ of PBS plus $0.05 \%$ $(\mathrm{w} / \mathrm{v})$ gelatin and $1 \mu \mathrm{l}$ of fluorescein isothiocyanate (FITC)-conjugated goat anti-mouse IgG (Boehringer-Manheim) incubated with the cells. The cells were washed again, resuspended in 400 $\mu l$ of PBS plus gelatin, and the relative amount of cell-bound FITC-conjugated antibody determined by a FACScan (Becton-Dickinson, Sparks, $\mathrm{MD)}$. 


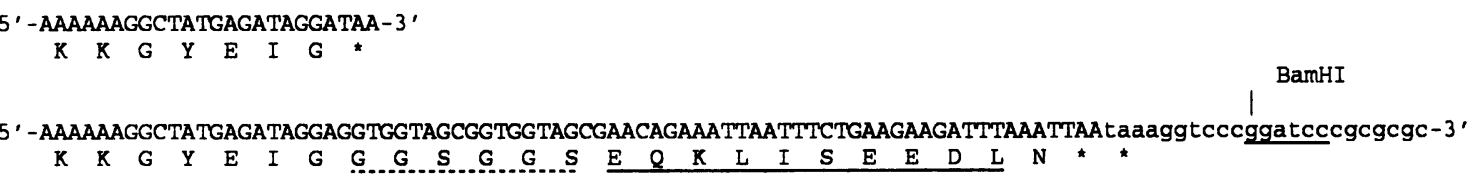

Fig. 1. Reverse-complement of the $3^{\prime}$ primer used to create PA-c-Myc by PCR amplification of the PA expression vector, pYS5. The top sequence is the $3^{\prime}$ wild-type PA sequence (25). The bottom sequence is the reverse complement of the 3' PCR primer encoding the 3' PA sequence, the linker (dashed underlined amino acids), the c-Myc

\section{Cytotoxicity Assays with MTT}

The macrophage lysis assay (28) was used to measure the toxicity of PA-c-Myc fusion protein on RAW264.7 macrophages. PA, as a control, or PA-c-Myc was added to one-third confluent, adherent RAW264.7 cells along with $100 \mathrm{ng} / \mathrm{ml}$ of LF in a 96-well microtiter dish to give a total volume of $200 \mu \mathrm{l} /$ well. PA SNKE $\Delta \mathrm{FF}$ (2), a nontoxic receptor-binding mutant of $\mathrm{PA}$, was used as a competitor in some of the wells. The PA or PA-c-Myc was serially diluted in the wells in the presence of a constant amount of LF and/or competitor. The cells were incubated for $3 \mathrm{hr}$ at $37^{\circ} \mathrm{C}$ in the presence of toxin, after which cell viability was assayed by adding $50 \mu \mathrm{l}$ of $0.5 \mathrm{mg} / \mathrm{ml}$ of MTT (3-[4,5-dimethylthiazol-2-yl]-2,5-diphenyltetrazolium bromide). The cells were incubated with the MTT for $45 \mathrm{~min}$ at $37^{\circ} \mathrm{C}$, the media removed, and the blue precipitate solubilized with $100 \mu \mathrm{l} /$ well of $0.5 \%(\mathrm{w} / \mathrm{v})$ SDS (sodium dodecyl sulfate), $25 \mathrm{mM} \mathrm{HCl}$, in $90 \%$ (v/v) isopropanol. The plates were vortexed and the intensity of the oxidized MTT read at $540 \mathrm{~nm}$ using the microplate reader.

\section{Cytotoxicity Assays with XTT}

Hybridoma cytotoxicity was assayed using XTT (2,3-bis[2-methoxy-4-nitro-5-sulfophenyl]-5[(phenylamino)carbonyl]-2H-tetrazolium hydroxide, inner salt, sodium salt) (29). One-third confluent cells was added to PA or PA-c-Myc serially diluted in the presence of a constant amount of $100 \mathrm{ng} / \mathrm{ml}$ of FP59, a fusion protein of the amino-terminal domain of $\operatorname{LF}(1-254)$ and the ADP-ribosylating domain of Pseudomonas exotoxin $\mathrm{A}(\mathrm{PE})$ that is similar to the fusion proteins described previously $(30,31)$. A constant amount of PA SNKE $\Delta \mathrm{FF}$ and/or c-Myc peptide was used as competitors in the assay to give a total volume of $250 \mu \mathrm{l} /$ well. The XTT was added epitope that corresponds to amino acids 410-419 of c-Myc (underlined amino acids) (17), and the unique BamHI restriction site (underlined nucleotides). The capital letters denote the gene sequence and the lowercase letters denote the noncoding vector sequence.

to the samples after the cells had been incubated with toxin for 50-60 hr. The XTT solution $(1 \mathrm{mg} / \mathrm{ml}$ of XTT in serum-free media and $25 \mu \mathrm{l}$ of $1.53 \mathrm{mg} / \mathrm{ml}$ of PMS [phenazine methosulfate] in acetone for every $5 \mathrm{ml}$ of XTT solution) was added to the wells at $50 \mu \mathrm{l} / \mathrm{well}$ and incubated at $37^{\circ} \mathrm{C}$ for $3-4 \mathrm{hr}$ to permit development of color. The optical density of the samples was determined at $405 \mathrm{~nm}$ in the Molecular Devices UVmax Kinetic Microplate Reader. The absorbance reading from the wells containing entirely dead cells was subtracted from the rest of the absorbance readings before calculating percent viability for the XTT assays.

\section{Statistics}

All samples were assayed in duplicate and the entire assay repeated three times. Standard errors were determined for the duplicate samples and presented as error bars on the graphs.

\section{Results}

\section{Construction and Purification of PA-c-Myc}

The c-Myc epitope was genetically fused to the $\mathrm{C}$-terminus of PA through a linker to ensure that the c-Myc epitope had enough flexibility to bind the antibody receptor (Fig. 1). Sequencing of the pYS5-c-myc plasmid indicated that the linker and c-myc epitope had inserted properly at the 3 '-end of pag (PA gene). The fusion protein was secreted at a concentration of approximately $10 \mathrm{mg} / \mathrm{l}$ into the medium and isolated by column chromatography to $99 \%$ purity, as determined by SDSPAGE. The PA-c-Myc eluted at $140 \mathrm{mM} \mathrm{NaCl}$ from the MonoQ column, as compared with the elution point of PA from the MonoQ column at $100 \mathrm{mM} \mathrm{NaCl}$. The purified PA-c-Myc also migrated faster than PA on a native gel, which is 


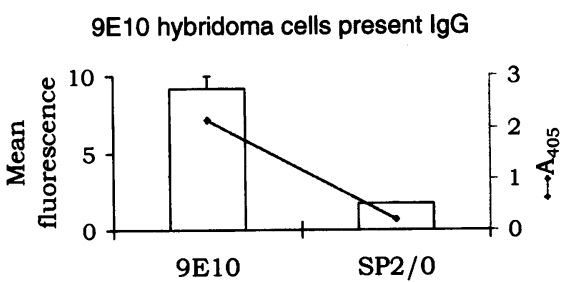

Fig. 2. The 9E10 mouse hybridoma cell line presents IgG on the cell surface. The relative amount of IgG on the cell surface was determined both by FACS and by immunoassay. FITC-conjugated goat anti-mouse IgG bound cells were analyzed by FACS and the results given as the mean fluorescence of the sorted cells (bar graph). For the immunoassay, the HRP-conjugated goat anti-mouse IgG bound cells were resuspended in ABTS and citrate buffer and the absorbance measured at $405 \mathrm{~nm}$ (line graph).

consistent with the incorporation of three negative charges from the added c-Myc epitope. In addition, the two proteins migrated to the same position on a denaturing SDS-Phast gel, corresponding to approximately $85 \mathrm{kDa}$, the $M_{\mathrm{r}}$ of PA $(32,33)$. The fusion protein showed no evidence of degradation on SDS-Phast gels after 6 months of storage at $-70^{\circ} \mathrm{C}$.

Immunoassays against $P A-c-M y c$ To Verify Presence of c-Myc Epitope

Antibody against c-Myc (9E10) and antibody against PA (3B6) were used in a serial dilution ELISA against PA, PA-c-Myc, and c-Myc peptide. The 9E10 antibody reacted with PA-c-Myc and c-Myc peptide and failed to detect PA, as expected (data not shown). The 9E10 antibody reaction with the c-Myc peptide produced an optical density twice that of the PA-c-Myc. The PA antibody 3B6 reacted with both PA-c-Myc and PA.

Immunoassays of Anti-c-Myc $9 E 10$ Mouse Hybridoma Cells To Confirm Presence of Antibody on the Cell Surface that Could Act as Receptors for $P A-c-M y c$

The 9E10 cell line was treated with HRP or FITCconjugated anti-mouse IgG (Fig. 2). The control for the experiments was the parent cell line of the hybridoma cell line, SP2/0, which is known to be Ig-negative (27). When incubated with the fluorescent antibody, the $9 \mathrm{E} 10$ cells had a peak mean of 9.18; the SP2/0 cells had a peak mean of 1.72. Similar results were obtained with the

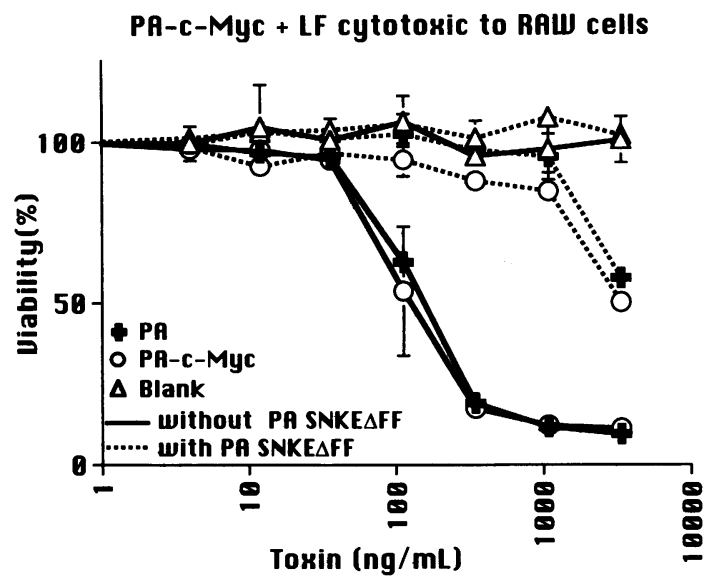

Fig. 3. PA and PA-c-Myc exhibit similar cytotoxic affects against RAW cells. PA and PA-cMyc were serially diluted into the 96 -well plates containing RAW cells, in the presence of $100 \mathrm{ng} / \mathrm{ml}$ of LF and with or without $5 \mu \mathrm{g} / \mathrm{ml}$ of the nontoxic competitive mutant of PA, PA SNKE $\Delta \mathrm{FF}$. The control samples without toxin are indicated as triangles. After $3 \mathrm{hr}$ of toxin challenge, MTT was added to determine cell viability.

HRP-conjugated anti-mouse IgG. The 9E10 cell line had 20 times as much absorbance $\left(2.1 \mathrm{~A}_{450}\right.$ after dilution factor correction) as the SP2/0 cell lines background absorbance $\left(0.133 \mathrm{~A}_{450}\right)$.

\section{Cytotoxicity Assay of PA-c-Myc + LF against RAW Cells}

Because fusion of the c-Myc epitope to PA could have created a nonfunctional fusion protein, the fusion protein's cytotoxicity was first tested on RAW cells, which are known to be lysed by the PA + LF toxin (Fig. 3). Both PA and PA-c-Myc killed RAW cells in an MTT cytotoxicity assay in the presence of LF, with a $50 \%$ effective concentration $\left(\mathrm{EC}_{50}\right)$ of approximately $100 \mathrm{ng} / \mathrm{mL}$. The nontoxic receptor-binding competitive inhibitor of PA, PA SNKE $\Delta \mathrm{FF}(5 \mu \mathrm{g} / \mathrm{ml})$, protected the cells equally well from both PA and PA-c-Myc, shifting the $\mathrm{EC}_{50}$ to greater than $3,000 \mathrm{ng} / \mathrm{ml}$.

Cytotoxicity Assay of PA and PA-c-Myc with FP59 against $9 E 10$ Hybridoma Cells

If the PA-c-Myc protein uses the 9E10 antibody to enter and kill hybridoma cells, the addition of the c-Myc peptide should compete with PA-cMyc binding and thus protect cells from toxin challenge. Alternatively, the PA-c-Myc might enter through the PA receptor. To test for PA 


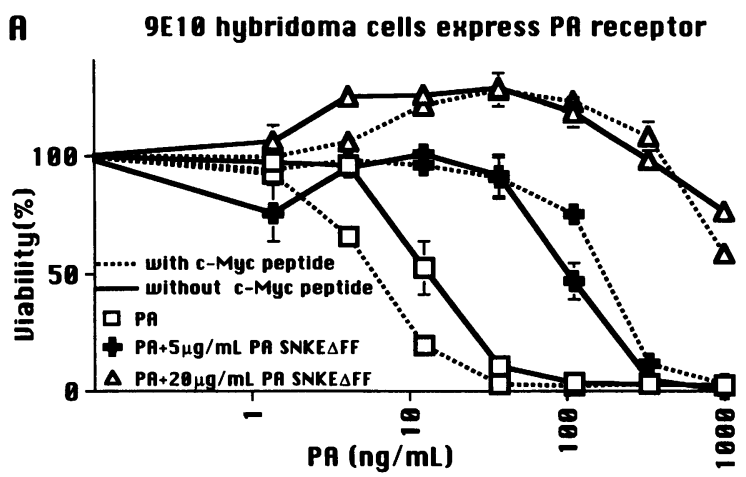

Fig. 4. PA-c-Myc uses c-Myc antibody to enter 9E10 hybridoma cells. PA (A) and PA-c-Myc (B) were serially diluted into $96-$ well plates in the presence of $100 \mathrm{ng} / \mathrm{ml}$ of the LF fusion, FP59, with or without the c-Myc peptide $(5.5 \mu \mathrm{g} / \mathrm{ml})$ as a competi-

receptor, PA was tested on the hybridoma cells using an XTT cytotoxicity assay (Fig. 4A). The cells expressed PA receptor because the PA killed the hybridoma cells with an $\mathrm{EC}_{50}$ of $10-30 \mathrm{ng} /$ $\mathrm{mL}$. In further experiments, the contribution of the PA receptor to the cytotoxicity of PA-cMyc + FP59 was blocked by the inclusion of the receptor-binding competitive inhibitor of PA, PA SNKE $\Delta \mathrm{FF}$. The cytotoxicity of PA + FP59 on $9 \mathrm{E} 10$ cells could be reduced with 5 and $20 \mu \mathrm{g} / \mathrm{ml}$ of PA SNKE $\triangle \mathrm{FF}$, shifting the $\mathrm{EC}_{50}$ to greater than 100 and $1000 \mathrm{ng} / \mathrm{ml}$, respectively (Fig. 4 and Table 1). The addition of c-Myc peptide as a competitor to the cytotoxicity assay caused a small increase in potency from 30 to $10 \mu \mathrm{g} / \mathrm{ml}$. However, this effect was not reproducible and
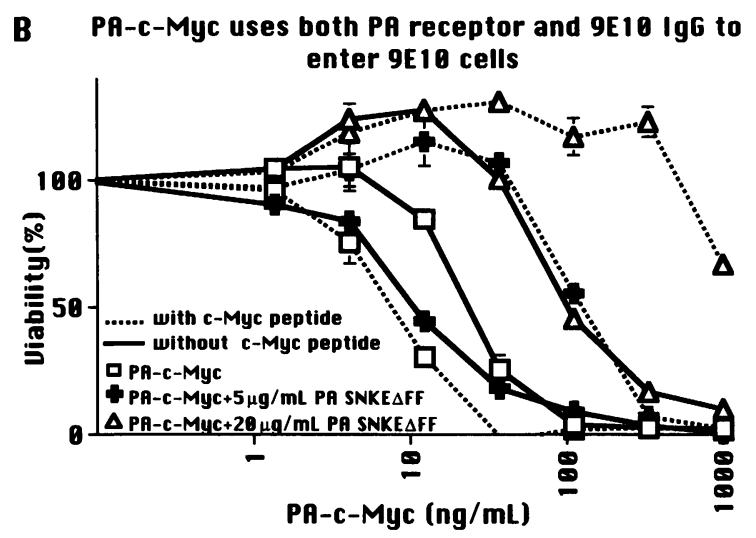

tor. Half of the samples also contained the additional competitor PA SNKE $\Delta$ FF at 0,5 , or $20 \mu \mathrm{g} / \mathrm{ml}$. After 50-60 hr of toxin challenge, XTT was added to determine cell viability.

was attributed to errors introduced during the performance of suspension cell assays.

When PA-c-Myc was tested on the 9E10 cells, the fusion protein killed the hybridoma cells with an $\mathrm{EC}_{50}$ of $50 \mathrm{ng} / \mathrm{ml}$ (Fig. 4B). To determine what portion of cell death was caused by entry of the toxin from the c-Myc receptor and what part was caused by entry from the PA receptor, c-MYc peptide and PA SNKE $\Delta$ FF were added as inhibitors. The PA SNKE $\Delta \mathrm{FF}$ at 20 $\mu \mathrm{g} / \mathrm{ml}$ inhibited cytotoxicity of the PA-c-Myc + FP59 to an $\mathrm{EC}_{50}$ of only $200 \mathrm{ng} / \mathrm{ml}$. A concentration of $5 \mu \mathrm{g} / \mathrm{ml}$ of PA SNKE $\Delta \mathrm{FF}$ did not seem to have any effect. The combination of the c-Myc peptide and the PA SNKE $\triangle F F$ increased the $\mathrm{EC}_{50}$ to greater than 100 and $1000 \mathrm{ng} / \mathrm{ml}$, for the 5

Table 1. Internalization of PA-c-Myc fusion protein mediated by cell surface anti-c-Myc antibodies on 9E10 hybridoma cells

$\mathrm{EC}_{50}$ in $\mathbf{n g} / \mathrm{mL}^{a}$

\begin{tabular}{|c|c|c|c|c|}
\hline Toxin & $\begin{array}{c}\text { With } \\
\text { Competitor }\end{array}$ & $\begin{array}{l}\text { With c-Myc } \\
\text { Peptide }^{b}\end{array}$ & $\begin{array}{c}\text { With } \\
\text { PA SNKE } \text { SFF }^{c}\end{array}$ & $\begin{array}{c}\text { With c-Myc } \\
\text { Peptide } \\
\text { and PA SNKE } \text { SFF }^{c}\end{array}$ \\
\hline PA-c-Myc & 50 & 10 & 100 & $>1000$ \\
\hline PA & 30 & 10 & $>1000$ & $>1000$ \\
\hline
\end{tabular}

${ }^{a} \mathrm{EC}_{50}$ is the concentration of toxin required to kill half of the cells compared with untreated controls. $\mathrm{EC}_{50}$ values are interpolated from Fig. 4A and $\mathrm{B}$.

${ }^{b} \mathrm{C}-\mathrm{Myc}$ peptide was used at $5.5 \mu \mathrm{g} / \mathrm{ml}$.

'PA SNKE $\Delta$ FF was used at $20 \mu \mathrm{g} / \mathrm{ml}$. 
and $20 \mu \mathrm{g} / \mathrm{ml}$ of PA SNKE $\Delta \mathrm{FF}$, respectively, which is similar to the effect of the PA SNKE $\Delta$ FF alone on the PA (see Table 1). When the c-Myc peptide was used alone at $5.5 \mu \mathrm{g} / \mathrm{ml}$, it failed to show a consistent effect on the $\mathrm{EC}_{50}$ of PA-cMyc. As the peptide failed to effect the cytotoxicity of the PA + FP59 toxin, the peptide was determined not to have any nonspecific effects on PA or PA-c-Myc receptor binding. In conclusion, the c-Myc epitope in combination with the PA SNKE $\Delta$ FF caused a greater than 10 -fold shift in the $\mathrm{EC}_{50}$ of PA-c-Myc when tested on 9E10 hybridoma cells, indicating that the PA-c-Myc was using the $9 \mathrm{E} 10$ antibody as a receptor to enter the cell.

\section{Discussion}

The PA-c-Myc fusion protein was created as a model system to test whether anthrax toxin could be targeted to an alternate receptor. Antic-Myc antibodies presented on the cell surface of the hybridoma cell line 9E 10 served as the alternate receptor. The addition of the c-Myc epitope to the C-terminus of PA did not interfere with the ability of the fusion protein to bind to the PA receptor. The fusion protein was able to kill RAW cells, which do not express c-Myc receptor, with an $\mathrm{EC}_{50}$ similar to that of wild-type PA (Fig. 3). After the endogenous PA receptors on 9E 10 cells were specifically blocked by adding the competitive inhibitor PA SNKE $\Delta F$, the PA-C-Myc still killed the 9E10 cells, indicating that the PA-CMyc used an alternate receptor, i.e., the 9E10 antibodies, to enter the cell (Fig. 4B). The results show that PA can be redirected to an alternate receptor.

Before testing the fusion protein on the 9E10 cells, immunoassays were used to verify that the fusion protein contained the c-Myc epitope and that the 9E 10 hybridoma cell line was presenting antibodies to c-Myc on its cell surface. Analysis of the fusion protein by ELISA showed that the 9E10 anti-c-Myc antibody bound the c-Myc peptide and produced an optical density twice that of the PA-c-Myc. This may be because there was much more $\mathrm{c}-\mathrm{Myc}$ peptide bound to the plate than PA-c-Myc on a molar basis. The overall results support the conclusion that the c-Myc epitope was attached to the PA-c-Myc fusion protein. Results from the immunoassay with the hybridoma cells verified that the 9E10 hybridoma cells present antibody on the cell surface (Fig. 2).
When PA SNKE $\Delta$ FF and the c-Myc peptide were added together to the hybridoma cells, the combination of the two competitors was able to protect the cells from PA-c-Myc toxin challenge, whereas the individual competitors by themselves were only partially effective or ineffective at preventing cell death (Fig. 4B). The PA SNKE $\Delta F F$ was less effective as a competitor for PA-c-Myc, compared with the effect of PA SNKE $\Delta$ FF on PA, because the PA-c-Myc appeared to use the $9 \mathrm{E} 10$ antibody as a receptor to enter the cell as well as the PA receptor. When tested against PA, the PA SNKE $\triangle \mathrm{FF}$ increased the $\mathrm{EC}_{50}$ of PA 1,000-fold, because the PA had no alternative receptor, whereas the PA-c-Myc could use the 9E10 antibody. The experiments clearly indicated that the c-Myc peptide in combination with the PA SNKE $\triangle \mathrm{FF}$ interfered with the ability of PA-c-Myc to bind to 9E10 cells. No attempt was made to quantitate the effect of the c-Myc peptide alone. As expected, the c-Myc peptide had no effect on PA + FP59 cytotoxicity.

In the present study, c-Myc was fused to PA and targeted to an alternate receptor. In many related studies, bacterial protein toxins have been targeted to alternate receptors using different methodologies. For instance, fusion of diphtheria toxin from Corynebacterium diphtheriae to protein A from Staphylococcus aureus created a toxin targeted to antibody-coated cells (33). This experiment demonstrated that diphtheria toxin could enter cells by attaching to antibodies instead of the toxin's native receptor. Also, the plant seed toxin, ricin, when fused to monoclonal antibodies against $\mathrm{T}$ cells, selectively inhibits the proliferation of $\mathrm{T}$ cells when added to a population of peripheral blood mononuclear cells (34). Pseudomonas exotoxin fused to single-chain antibodies against interleukin-2 (IL-2) targets IL-2 receptors on human cell lines (35). Alternatively, instead of using antibodies to target a specific cell type, the ligand for the receptor could be used to target the cell. The diphtheria toxin receptor-binding domain was replaced with the 11-amino acid epitope for substance P, thereby targeting substance $P$ receptors on nerve cells (36). A similar strategy was used for Pseudomonas exotoxin where several ligands, such as IL-2, IL-4, and insulin growth factor-1, have been fused to the toxin and used to target various cell lines (for reviews on Pseudomonas exotoxin, see ref. 37).

Anthrax toxin may have advantages over other single-chain toxins like diphtheria toxin and Pseudomonas exotoxin. Bacillus anthracis syn- 
thesizes as separate proteins the two catalytic components of the toxin and the single receptorbinding component. Thus, while the single-chain toxins mentioned above are intrinsically toxic, the anthrax toxin components are synthesized as independent proteins that are not toxic until combined (3). Because lethal toxin and edema toxin are two-protein toxins, the receptor binding component, PA, can be manipulated independently without affecting the catalytic moieties of the toxins LF and EF. Also, LF can be separately engineered to deliver novel proteins to eukaryotic cells, such as the catalytic domains of tetanus toxin (38), shiga toxin (39), and diphtheria toxin $(39,40)$. Fusion of the catalytic domains of these toxins to the 254-amino acid $\mathrm{N}$-terminal domain of LF creates proteins that are able to bind PA and use PA to enter cells expressing receptors for PA.

Even though the fusion of c-Myc to PA created a toxin capable of using an alternate receptor, the toxin was still capable of using the native PA receptor. Future studies on PA will focus on the replacement of the receptor-binding domain of PA with cell-specific ligands, such as CD4, IL-2, and single-chain antibodies (as discussed in a recent review, see ref. 41). These fusions can be used to target HIV-infected cells or tumor cells. Alternatively, the receptor-binding domain of PA can be mutated to create a PA that does not bind its own receptor, so that the addition of novel epitopes to the C-terminus of the altered PA will enable the creation of cell-specific anthrax toxins.

\section{Acknowledgments}

The authors are grateful to Valery Gordon for helpful discussions in the preparation of this manuscript.

\section{References}

1. Smith H, Keppie J, Stanley JL (1955) The chemical basis of the virulence of Bacillus anthracis. V. The specific toxin produced by $B$. anthracis in vivo. Br. J. Exp. Pathol. 36: 460-472.

2. Klimpel KR, Molloy SS, Thomas G, Leppla SH (1992) Anthrax toxin protective antigen is activated by a cell-surface protease with the sequence specficitiy and catalytic properties of furin. Proc. Natl. Acad. Sci. U.S.A. 89: 10277-10281.

3. Friedlander AM (1986) Macrophages are sensitive to anthrax lethal toxin through an acid-dependent process. J. Biol. Chem. 261: 7123-7126.
4. Gordon VM, Leppla SH, Hewlett EL (1988) Inhibitors of receptor-mediated endocytosis block the entry of Bacillus anthracis adenylate cyclase toxin but not that of Bordetella pertussis adenylate cyclase toxin. Infect. Immun. 56: 1066-1069.

5. Milne JC, Furlong D, Hanna PC, Wall JS, Collier RJ (1994) Anthrax protective antigen forms oligomers during intoxication of mammalian cells. J. Biol. Chem. 269: 20607-20612.

6. Leppla SH (1991) The anthrax toxin complex. In: (ed Alouf JE, Freer JH) Sourcebook of Bacterial Protein Toxins. Academic Press, London, pp. 277-302.

7. Leppla S (1995) Anthrax toxins. In: (ed Moss J, Iglewski B, Vaughan M, Tu A) Bacterial Toxins and Virulence Factors in Disease. Handbook of Natural Toxins, Vol. 8 Marcel Dekker, New York, pp. 543-572.

8. Beall FA, Taylor MJ, Thorne CB (1962) Rapid lethal effect in rats of a third component found upon fractionating the toxin of Bacillus anthracis. $J$. Bacteriol. 83: 1274-1280.

9. Ezzell JW, Ivins BE, Leppla SH (1984) Immunoelectrophoretic analysis, toxicity, and kinetics of in vitro production of the protective antigen and lethal factor components of Bacillus anthracis toxin. Infect. Immun. 45: 761-767.

10. Hanna PC, Kouchi S, Collier RJ (1992) Biochemical and physiological changes induced by anthrax lethal toxin in J774 macrophage-like cells. Mol. Biol. Cell 3: 1269-1277.

11. Singh Y, Klimpel KR, Quinn CP, Chaudhary VK, Leppla SH (1991) The carboxyl-terminal end of protective antigen is required for receptor binding and anthrax toxin activity. J. Biol. Chem. 266: 15493-15497.

12. Little SF, Leppla SH, Cora E (1988) Production and characterization of monoclonal antibodies to the protective antigen component of Bacillus anthracis toxin. Infect. Immun. 56: 1807-1813.

13. Perelle S, Gibert M, Boquet P, Popoff MR (1993) Characterization of Clostridium perfringens iotatoxin genes and expression in Escherichia coli. Infect. Immun. 61: 5147-5156.

14. Petosa C, Collier RJ, Klimpel KR, Leppla SH, Liddington RC (1997) Crystal structure of the anthrax toxin protective antigen. Nature 385: 833838.

15. Ramsay G, Evan GI, Bishop JM (1984) The protein encoded by the human proto-oncogene cmyc. Proc. Natl. Acad. Sci. U.S.A. 81: 7742-7746.

16. Kolodziej PA, Young RA (1991) Epitope tagging and protein surveillance. Methods Enzymol. 194: 508-519.

17. Evan GI, Lewis GK, Ramsay G, Bishop JM (1985) Isolation of monoclonal antibodies specific for human c-myc proto-oncogene product. Mol. Cell. Biol. 5: 3610-3616.

18. Koskinen PJ, Alitalo K (1993) Role of myc amplification and overexpression in cell growth, differentiation and death. Semin. Cancer Biol. 4: 3-12.

19. Vastrik I, Makela TP, Koskinen PJ, Klefstrom J, 
Alitalo K (1994) Myc protein: Partners and antagonists. Crit. Rev. Oncog. 5: 59-68.

20. Ryan KM, Birnie GD (1996) Myc oncogenes: The enigmatic family. Biochem. J. 314: 713-721.

21. DeFranco AL (1992) Tyrosine phosphorylation and the mechanism of signal transduction by the B-lymphocyte antigen receptor. Eur. J. Biochem. 210: $381-388$.

22. Reth M (1992) Antigen receptors on B lymphocytes. Annu. Rev. Immunol. 10: 97-121.

23. Reth M, Hombach J, Wienands J, Campbell KS, Chien N, Justement LB, Cambier JC (1991) The $\mathrm{B}$-cell antigen receptor complex. Immunol. Today 12: 196-201.

24. Singh Y, Chaudhary VK, Leppla SH (1989) A deleted variant of Bacillus anthracis protective antigen is non-toxic and blocks anthrax toxin action in vivo. J. Biol. Chem. 264: 19103-19107.

25. Welkos SL, Lowe JR, Eden-McCutchan F, Vodkin M, Leppla SH, Schmidt JJ (1988) Sequence and analysis of the DNA encoding protective antigen of Bacillus anthracis. Gene 69: 287-300.

26. Quinn CP, Dancer BN (1990) Transformation of vegetative cells of Bacillus anthracis with plasmid DNA. J. Gen. Microbiol. 136: 1211-1215.

27. Shulman M, Wilde CD, Kohler G (1978) A better cell line for making hybridomas secreting specific antibodies. Nature 276: 269-270.

28. Quinn CP, Singh Y, Klimpel KR, Leppla SH (1991) Functional mapping of anthrax toxin lethal factor by in-frame insertion mutagenesis. J. Biol. Chem. 266: 20124-20130.

29. Scudiero DA, Shoemaker RH, Paull KD, Monks A, Tierney S, Nofziger TH, Currens MJ, Seniff D, Boyd MR (1988) Evaluation of a soluble tetrazolium/formazan assay for cell growth and drug sensitivity in culture using human and other tumor cell lines. Cancer Res. 48: 4827-4833.

30. Arora N, Klimpel KR, Singh Y, Leppla SH (1992) Fusions of anthrax toxin lethal factor to the ADPribosylation domain of Pseudomonas exotoxin A are potent cytotoxins which are translocated to the cytosol of mammalian cells. J. Biol. Chem. 267: 15542-15548.

31. Arora N, Leppla SH (1993) Residues 1-254 of anthrax toxin lethal factor are sufficient to cause cellular uptake of fused polypeptides. J. Biol. Chem. 268: 3334-3341.

32. Leppla SH (1988) Production and purification of anthrax toxin. Methods Enzymol. 165: 103-116.

33. Madshus IH, Stenmark H, Sandvig K, Olsnes S (1991) Entry of diphtheria toxin-protein A chimeras into cells. $J$. Biol. Chem. 266: 17446-17453.

34. Vallera DA, Ash RC, Zanjani ED, Kersey JH, LeBien TW, Beverley PC, Neville, Jr, DM, Youle RJ (1983) Anti-T-cell reagents for human bone marrow transplantation: Ricin linked to three monoclonal antibodies. Science 222: 512-515.

35. Chaudhary VK, Queen C, Junghans RP, Waldmann TA, FitzGerald DJ, Pastan I (1989) A recombinant immunotoxin consisting of two antibody variable domains fused to Pseudomonas exotoxin. Nature 339: 394-397.

36. Fisher CE, Sutherland JA, Krause JE, Murphy JR, Leeman SE, vanderSpek JC (1996) Genetic construction and properties of a diphtheria toxinrelated substance $P$ fusion protein: In vitro destruction of cells bearing substance $\mathrm{P}$ receptors. Proc. Natl. Acad. Sci. U.S.A. 93: 7341-7345.

37. FitzGerald D, Pastan I (1991) Redirecting Pseudomonas exotoxin. Semin. Cell Biol. 2: 31-37.

38. Arora N, Williamson LC, Leppla SH, Halpern JL (1994) Cytotoxic effects of a chimeric protein consisting of tetanus toxin light chain and anthrax toxin lethal factor in non-neuronal cells. J. Biol. Chem. 269: 26165-26171.

39. Arora N, Leppla SH (1994) Fusions of anthrax toxin lethal factor with shiga toxin and diphtheria toxin enzymatic domains are toxic to mammalian cells. Infect. Immun. 62: 4955-4961.

40. Milne JC, Blanke SR, Hanna PC, Collier RJ (1995) Protective antigen-binding domain of anthrax lethal factor mediates translocation of a heterologous protein fused to its amino- or carboxy-terminus. Mol. Microbiol. 15: 661-666.

41. Leppla SH, Klimpel KR, Arora N (1994) Development of anthrax toxin-based fusion proteins for targeting of HIV-1-infected cells. In: Fehrenbach F (ed). Bacterial Protein Toxins. Gustav Fischer Verlag, Stuttgart, pp. 431-442. 